

American Journal of Biomedical Sciences

ISSN: 1937-9080

nwpii.com/ajbms

\title{
The Prophylactic Antioxidant and Hepatoprotective Potential of Garcinia Kola Pretreatment in Acetaminophen Induced Toxicity in Albino Rats
}

\author{
*Bartimaeus, Ebirien-Agana Samuel'; Waribo, Helen Anthony² \\ ${ }^{1}$ Department of Medical Laboratory Science, Rivers State University, Nkpolu-Oroworukwu.Port Harcourt, Nigeria \\ ${ }^{2}$ School of Medical Laboratory Science, Rivers State College of Health Science and Technology, Oro-Owo Rumueme. \\ Port Harcourt, Rivers State, Nigeria. \\ *Corresponding Author \\ Bartimaeus, Ebirien-Agana Samuel \\ Department of Medical Laboratory Science, \\ Rivers State University, \\ Nkpolu-Oroworukwu, Port Harcourt, Rivers State, \\ Nigeria \\ E-Mail:ebbyagana@gmail.com \\ Phone:+2348033410302 \\ Received:05 May 2018; | Revised:25 May 2018; | Accepted:03 June 2018
}

\begin{abstract}
This study was designed to evaluate the prophylactic antioxidant and hepatoprotective potential of Garcinia kola pretreatment in albino rats. A total number of 20 Albino rats comprising both males and females weighing about $\pm 100 \mathrm{~g}$ were used. The rats were divided into 4 groups of five rats each. The testing involved pretreatment with Garcinia kola seed extract at a low and high dose respectively for a period of seven (7) days before they were induced with acetaminophen intraperitoneally on the 8th day by gavage administration. They were fasted over night and then sacrificed on the 9th day under chloroform anaesthesia and blood was collected for biochemical and oxidative stress markers analyses using standardized procedures by cardiac puncture into plain tubes. The activities of the liver enzymes ALT, AST and ALP and MDA were significantly increased $(\mathrm{p}<0.05)$ and SOD, CAT and GSH-Px significantly decreased $(\mathrm{p}<0.05)$ in the animals induced with acetaminophen when compared with the control animals. However, pretreatment administration of Garcinia kola extract resulted in significant reduction $(\mathrm{p}<0.05)$ in the activities of these enzymes and MDA and a significant increase $(\mathrm{p}<0.05)$ in the activities of SOD, CAT and GSH-Px in both the low and high doses Garcinia kola extract groups respectively in the animals. The implication of these findings is that the extracts of Garcinia kola seed possess potential prophylactic antioxidant and hepatoprotective effects in rats when given as a pretreatment before exposure to the hepatotoxic agent which supports the traditional prophylactic use of Garcinia kola in hepatotoxic disorders, hepatitis and jaundice.
\end{abstract}


Keywords: Hepatotoxicity, Malondialdehyde, Superoxide dismutase, Catalase, Gutathione peroxidase, Liver enzymes, Oxidative stress

\section{Introduction}

Garcinia kola Heckel (family Guttifera) is a dicotyledonous plant found in most forest in Nigeria. The seeds have a bitter taste. As a result the plant is commonly called bitter kola in Nigeria. Bitter kola seeds are being consumed as a stimulant ${ }^{[1]}$. It has been reported that the seeds have been used as remedies in the treatment of some liver disorders, and diarrhoea ${ }^{[2,3]}$, diabetes, bronchitis and throat infections ${ }^{[4,5]}$. G. kola has been reported to possess some hepatoprotective and aphrodisiac properties ${ }^{[6-}$ ${ }^{8]}$. G. kola has also been shown to contain a high content of biflavonoid compounds ${ }^{[9]}$ which are responsible for its remarkable bioactivities due to their enormous antioxidant activities ${ }^{[10]}$.

Liver is a major organ normally attacked by reactive oxygen species (ROS) ${ }^{[11]}$. Excessive generation of ROS causes a disturbance of the body homeostasis resulting in oxidative stress, which plays a critical role in liver diseases and other chronic and degenerative disorders ${ }^{[12]}$. The oxidative stress only triggers hepatic damage by inducing irretrievable alteration of lipids, proteins and DNA contents and more importantly, modulating pathways that control normal biological functions ${ }^{[13]}$. Hepatic injury often manifest in the release of enzymes such as aspartate amino transferase (AST), alanine amino transferase (ALT) and alkaline phosphatase (ALP) in the plasma.

To enable the body cope with oxidative stress under physiological condition, both enzymatic and non-enzymatic antioxidant systems are essential. Therefore, antioxidant enzyme such as catalase (CAT), superoxide dismutase (SOD), and glutathione peroxidase (GSH-Px) are affected and used as indexes to evaluate the level of oxidative stress ${ }^{[14-16]}$. Most studies with G. kola involved inducing hepatotoxicity and damage with the toxic agent and later treatment of the animals with Garcinia kola to evaluate the potential of G. kola to revert the damages done by the toxic agent. In this study, the animals were pretreated with G. kola for 7 days and induced with a toxic agent (acetaminophen) to evaluate the capacity of
Garcinia kola to offer protection against the toxicity inducing agent. This study was, therefore, designed to evaluate the prophylactic antioxidant and hepatoprotective potential of Garcinia kola pretreatment in albino rats.

\section{Materials and Methods}

Garcinia kola paste preparation: The seeds of Garcinia kola were purchased from Mile 1 Market, Diobu, in Port Harcourt in Rivers State, Nigeria. The seeds were sorted to remove any contaminants, dead matter, sand particles and then air dried for some days. Two (2) $\mathrm{kg}$ of Garcinia kola nuts were oven dried at $45^{\circ} \mathrm{C}$ and ground using a grinding machine. The pulverized powder was macerated in a maceration jar with distilled water for twenty four hours. During the period of maceration, it was well shaken three times and filtered repeatedly using Whatman No.1 filter paper. The filtration process was repeated for about 2-3 times to have a clear filtrate. The clear filtrate was later heated in an evaporating dish at $45^{\circ} \mathrm{C}$ leaving the extract in a brownish paste like form.

Acetaminophen:Commercially available acetaminophen was purchased from Carbosynth Company, Unit 8 and 9, Old Station Business PK, Compton, RG20 SNE United Kingdom. Other reagents and chemicals used in the study were of analytical grade and purest quality.

Estimation of LD50 of Garcinia kola: A total number of 15 rats made up of both males and females with an average weight of $80-120 \mathrm{~g}$ were used to determine the LD50 of the aqueous Garcinia kola extract following acute toxicity exposure as reported by ${ }^{[17,18]}$.

Experimental animals: A total number of 20 Albino rats made up of both males and females weighing between $80-120 \mathrm{~g}$ were used for the study. These animals were procured from the animal house of the Department of Pharmacology, Faculty of Basic Medical Science, University of Port Harcourt. The animals were kept in a well ventilated cage with 12 hours natural light/dark cycle. They were divided into groups and allowed to acclimatize for 2 
weeks to enable them get used to the handling process during the research process. They were fed with commercially prepared rat feed (finisher) which was purchased from the Top Feed Company, Eastern Premier Feed Mill Ltd, Aba, Abia State, Nigeria and had access to water (ad libitum) throughout the period. The conditions of the animals were in conformity with standards as outlined by the National Academy of Science ${ }^{[19-21]}$.

\section{Experimental Design:}

Experimental test. The 20 rats with weight between $80-120 \mathrm{~g}$ were divided into four groups comprising five (5) animals each. The testing involved pretreatment with Garcinia kola seed extract by gavage administration for seven days depending on their specified treatment regimen i.e a low and high dose of G. kola seed extract respectively within the therapeutic dose. The animals were exposed to varying doses of the extract under study for a period of seven (7) days before they were induced with acetaminophen intraperitoneally on the 8th day.

Treatment Regimen: A modified experimental procedure according to Folarin et al. ${ }^{[22]}$ was adopted. The albino rats were divided into four (4) groups of five (rats) each. Rats in group A (control group) were giving normal feed and distilled water and isotonic $0.9 \% \mathrm{NaCl}$ solution was given to them on the 8th day. Group B is the acetaminophen induced toxicity group (AIG) received distilled water for 7 days and intoxicated with $800 \mathrm{mg}$ acetaminophen intraperitoneally on the 8th day. Group C which is the low dose Garcinia kola extract plus acetaminophen induced group (LDGKAG) was pretreated with $100 \mathrm{mg} / \mathrm{kg}$ of Garcinia kola seed extract for 7 days and then intoxicated with $800 \mathrm{mg}$ acetaminophen intraperitoneally on the 8th day while Group Dhigh dose Garcinia kola extract plus acetaminophen induced group (HDGKAG) was pretreated with $800 \mathrm{mg} / \mathrm{kg}$ of Garcinia kola seed extract for 7 days and then intoxicated with $800 \mathrm{mg}$ acetaminophen intraperitoneally on the 8th day. They were fasted overnight and then sacrificed on the 9th day under chloroform anaesthesia ${ }^{[23]}$, and blood was collected for biochemical and oxidative stress markers analysis by cardiac puncture into plain tubes.

Collection/preparation of serum: Blood samples were collected by cardiac puncture into plain bottles and then allowed to stand for proper clotting and retraction. Serum was gotten from centrifuging at $3000 \mathrm{rpm}$ for $15 \mathrm{mins}$ in a bench centrifuge. The clear supernatant was used for the biochemical analyses.

Biochemical determinations: ALT and AST activities were determined by the method of Reitman and Frankel ${ }^{[24]}$ while ALP was determined using the colorimetric method as described by ${ }^{[25]}$. MDA was estimated using spectrophotometric method ${ }^{[26]}$ while the determination of CAT activity was done by the spectrophotometric method of Aebi [27]. The estimation of the SOD activity was achieved using the auto-oxidation method of Misra and Fridovich ${ }^{[28]}$. The activity of GSH-Px enzyme activity in the serum was determined according to the method of Rotruck et al. ${ }^{[29]}$.

Statistical analysis: All values were expressed as mean $\pm \mathrm{SD}(\mathrm{n}=5$ in each group). One-way analysis of variance (ANOVA) was applied to test for significance of liver function and antioxidant parameters. The Tukey multiple comparison test was used to test for differences in means between the different groups. The Graph Pad Instant Version 3.10.12 bit for Windows soft wares was used for the computation of data. Values were considered significant at $\mathrm{p}<0.05$.

\section{Results}

$\boldsymbol{A L T}$ : The mean \pm SD of the activity of ALT in the control albino rats was $34.20 \pm 1.64 \mathrm{U} / \mathrm{L}$. Upon administration of acetaminophen the value increased to $98.60 \pm 0.89 \mathrm{U} / \mathrm{L}$. However, the values were drastically reduced in the group of albino rats that were pretreated with low dose Garcinia kola $(51.60 \pm 1.52 \mathrm{U} / \mathrm{L})$ and high dose Garcinia kola $(51.60 \pm 1.52 \mathrm{U} / \mathrm{L})$ respectively. The variation in means were significantly different $(p<0.0001)$ when compared with that of the albino rats in the control group. The comparison of the means of ALT activity in the hepatotoxic group and the pretreated groups showed significant difference $(p<0.05)$. It was also observed that the activity of ALT was lowest in the group that was pretreated with high dose Garcinia kola and the decrease was not significant $(\mathrm{p}>0.05)$ when compared with mean of the low dose Garcinia kola pretreated group. 
Table 1:Mean \pm SD of liver function and antioxidant parameters in normal and albino rats pretreated with $\mathbf{G}$. kola and induced with acetaminophen

\begin{tabular}{cccccc}
\hline $\begin{array}{c}\text { Group } \\
\text { Parameters }\end{array}$ & $\begin{array}{c}\text { Group A } \\
\text { Control }\end{array}$ & $\begin{array}{c}\text { Group B } \\
\text { AIG }\end{array}$ & $\begin{array}{c}\text { Group C } \\
\text { LDGKAG }\end{array}$ & $\begin{array}{c}\text { Group D } \\
\text { HDGKAG }\end{array}$ & P value \\
\hline ALT $(\mathrm{U} / \mathrm{L})$ & $34.20 \pm 1.64$ & $98.60 \pm 0.89^{\mathrm{a}}$ & $51.60 \pm 1.52^{\mathrm{ab}}$ & $50.60 \pm 0.89^{\mathrm{abe}}$ & $\mathrm{P}<0.0001$ \\
AST $(\mathrm{U} / \mathrm{L})$ & $52.60 \pm 1.52$ & $100.60 \pm 1.14^{\mathrm{a}}$ & $89.00 \pm 0.84^{\mathrm{ab}}$ & $82.20 \pm 4.44^{\mathrm{abc}}$ & $\mathrm{P}<0.0001$ \\
ALP $(\mathrm{U} / \mathrm{L})$ & $47.40 \pm 1.14$ & $138.40 \pm 2.30^{\mathrm{a}}$ & $48.60 \pm 0.89^{\mathrm{bd}}$ & $50.80 \pm 1.64^{\mathrm{abe}}$ & $\mathrm{P}<0.0001$ \\
MDA $(\mu \mathrm{mol} / \mathrm{ml})$ & $2.35 \pm 0.02$ & $6.82 \pm 0.36^{\mathrm{a}}$ & $2.82 \pm 0.18^{\mathrm{ab}}$ & $2.87 \pm 0.01^{\text {abe }}$ & $\mathrm{P}<0.0001$ \\
SOD $(\mu \mathrm{g} / \mathrm{ml})$ & $7.54 \pm 0.06$ & $4.89 \pm 0.06^{\mathrm{a}}$ & $7.53 \pm 0.02^{\mathrm{ad}}$ & $7.85 \pm 0.15^{\mathrm{abc}}$ & $\mathrm{P}<0.0001$ \\
CAT $(\mathrm{U} / \mathrm{mg})$ & $0.47 \pm 0.03$ & $0.15 \pm 0.01^{\mathrm{a}}$ & $0.37 \pm 0.02^{\mathrm{ab}}$ & $0.44 \pm 0.02^{\mathrm{abc}}$ & $\mathrm{P}<0.0001$ \\
GSH-Px $(\mu \mathrm{g} / \mathrm{ml})$ & $29.67 \pm 0.41$ & $20.57 \pm 0.01^{\mathrm{a}}$ & $29.58 \pm 0.03^{\text {bd }}$ & $30.72 \pm 0.21^{\mathrm{abc}}$ & $\mathrm{P}<0.0001$ \\
\hline
\end{tabular}

Keys: $\mathrm{a}=$ significantly different from group $\mathrm{A} ; \mathrm{b}=$ significantly different from group $\mathrm{B} ; \mathrm{c}=$ significantly different from Group C, $d=$ not significantly different from Group A; $\mathrm{e}=$ not significantly different from Group C. ALT= alanine amino transferase, AST $=$ aspartate amino transferase, ALP $=$ alkaline phosphatase, MDA $=$ malondialdehyde, $\mathrm{SOD}=$ superoxide dismutase, $\mathrm{CAT}=$ catalase, $\mathrm{GSH}-\mathrm{Px}=$ glutathione peroxidase, $\mathrm{AIG}=$ acetaminophen induced group $\mathrm{LDGKAG}=$ low dose $\mathrm{G}$. kola group, $\mathrm{HDGKAG}=$ high dose $\mathrm{G}$. kola group.

$\boldsymbol{A S T}$ : The mean $\pm \mathrm{SD}$ of the activity of AST of the albino rats in the control group was $52.60 \pm 1.52$ $\mathrm{U} / \mathrm{L}$ while the mean of the hepatotoxicity group was $100.60 \pm 1.14 \mathrm{U} / \mathrm{L}$ and Garcinia kola pretreated groups $89.00 \pm 0.84 \mathrm{U} / \mathrm{L}$ (low dose Garcinia kola group) and $82.20 \pm 4.44 \mathrm{U} / \mathrm{L}$ (high dose Garcinia kola group) respectively. The means were also significantly different $(\mathrm{p}<0001)$. Comparison of means between the groups showed that significant difference $(p<0.05)$ exist between the hepatotoxicity groups, the low and high dose Garcinia kola

pretreated groups and the control group. The means of the low and high dose Garcinia kola pretreated groups were also significantly different $(p<0.05)$ from the mean of the acetaminophen induced group. Significant difference $(p<0.05)$ in mean was also seen between the mean of the low dose G. kola pretreated and high dose G. kola pretreated group.

ALP: Remarkable increase in the activity of the ALP enzyme was also seen between the groups. Administration of acetaminophen caused increase in the mean of the activity of the enzyme from 47.40 $\pm 1.14 \mathrm{U} / \mathrm{L}$ (control group) to $138.40 \pm 2.30 \mathrm{U} / \mathrm{L}$ in the induced group. However, in the pretreated groups, protective potential was seen as the mean values decreased to $48.60 \pm 0.89 \mathrm{U} / \mathrm{L}$ (low dose $\mathrm{G}$. kola group) and $50.80 \pm 1.64 \mathrm{U} / \mathrm{L}$ respectively. These variations in means of the enzyme activity was significantly different $(p<0.0001)$. While significant difference $(p<0.05)$ was observed between the means of the control, acetaminophen induced and high dose G. kola pretreated groups, comparison of the mean of the control with the low dose G. kola showed no significant difference $(\mathrm{p}>0.05)$.

$M D A$ : The mean \pm SD of MDA in the albino rats of the control group was $2.35 \pm 0.02 \mu \mathrm{mol} / \mathrm{mL}$ while the value for acetaminophen induced toxicity group was $6.82 \pm 0.36 \mu \mathrm{mol} / \mathrm{mL}$. In the pretreated groups, the low dose G. kola group had a lower mean of $2.82 \pm 0.18 \mu \mathrm{mol} / \mathrm{mL}$ while the high dose G. kola group had a mean of $2.87 \pm 0.01 \mu \mathrm{mol} / \mathrm{mL}$. Comparison of the means of the various groups using analysis of variance (ANOVA) showed significant difference $(p<0.0001)$. The Tukey multiple comparison of the means showed that the means of the pretreated groups and the acetaminophen induced toxicity groups were significantly different $(\mathrm{p}<0.05)$ from the mean of the control group while the means of the pretreated groups were significantly different $(\mathrm{p}<0.05)$ from the mean of the acetaminophen induced toxicity group. However, no significant difference $(p>0.05)$ in mean was seen in the mean of MDA between the low dose G. kola and high dose G. kola pretreated groups. 
SOD: The mean $\pm \mathrm{SD}$ of the antioxidant enzyme of the albino rats in the control group was $7.54 \pm 0.06 \mu \mathrm{g} / \mathrm{mL}$ while that of the acetaminophen induced toxicity group was $4.89 \pm 0.06 \mu \mathrm{g} / \mathrm{mL}$. In the G. kola pretreated groups, the SOD level was $7.53 \pm 0.02 \mu \mathrm{g} / \mathrm{mL}$ in the low dose Garcinia kola group and $7.85 \pm 0.15 \mu \mathrm{g} / \mathrm{mL}$ in the high dose Garcinia kola group and the increase in the enzyme activity between the groups was significant $(p<0.0001)$. A comparison of the means using Tukey multiple comparison test showed that the means of the pretreated groups and the acetaminophen induced toxicity groups were also significantly $\mu$ different $(p<0.05)$ from the mean of the control group. While the mean of the SOD in the high dose G. kola pretreated group was significantly different $(p<0.05)$ from the mean of the acetaminophen induced toxicity group and the low dose G. kola pretreated group, the mean of SOD in the low dose G. kola pretreated group was not significantly different $(p>0.05)$ from that of the control group.

$\boldsymbol{C A T}$ : The mean of the enzymatic antioxidant enzyme, CAT of the albino rats in the various groups was also evaluated. Results show that the mean \pm SD of CAT in the control group was $0.47 \pm$ $0.03 \mathrm{U} / \mathrm{mg}$ while that of the acetaminophen induced toxicity group was $0.15 \pm 0.01 \mathrm{U} / \mathrm{mg}$. In the low dose G. kola pretreated group, the mean of CAT was $0.37 \pm 0.02 \mathrm{U} / \mathrm{mg}$ while that of the high dose $\mathrm{G}$. kola pretreated group was $0.44 \pm 0.02 \mathrm{U} / \mathrm{mg}$. Comparison of the means of various groups using ANOVA showed significant difference $(\mathrm{p}<0.0001)$. However, Tukey multiple comparison test analysis of the means showed that the mean of the acetaminophen induced toxicity group, the low dose G. kola pretreated group and the mean of CAT in the high dose G. kola pretreated group were significantly different $(\mathrm{p}<0.05)$ from that of the control group. Similarly, the means of CAT in the low dose G. kola pretreated group and high dose G. kola pretreated group were significantly different $(p<0.05)$ from that of the acetaminophen induced toxicity group while the means of CAT in the low dose G. kola pretreated group and high dose G. kola pretreated group were significantly different $(p<0.05)$ from each other.
GSH-Px: Furthermore, the evaluated means of GSH-Px enzyme of the albino rats in the control and the acetaminophen induced toxicity groups were $29.67 \pm 67 \mu \mathrm{g} / \mathrm{mL}$ and $20.57 \pm 0.001 \mu \mathrm{g} / \mathrm{mL}$ respectively while that of the low dose G. kola pretreated and high dose G. kola pretreated groups were $29.58 \pm 58 \mu \mathrm{g} / \mathrm{mL}$ and $30.72 \pm 0.21 \mu \mathrm{g} / \mathrm{mL}$ respectively. The means of the treatment groups were significantly different $(p<0.0001)$ from each other. However, while the mean of glutathione peroxidase in the acetaminophen induced toxicity group and high dose G. kola pretreated groups were significantly different $(p<0.05)$ from the mean of the control group, the mean of the low dose G. kola pretreated group was not. The means of the low dose G. kola pretreated and high dose G. kola pretreated groups were also significantly different $(p<0.05)$ from the mean of the acetaminophen induced toxicity group. Significant difference $(p<0.05)$ was also seen between the means of glutathione peroxidase between the low dose $\mathrm{G}$. kola pretreated and high dose G. kola pretreated groups.

\section{Discussion}

Several hepatotoxins such as paracetamol, carbon tetrachloride, tioacetamide, gaketosamine, phallodine, 1, 2-dimethylhydrazine and ethanol have been used to successfully caused hepatoxicity in the liver cells of abino rats ${ }^{[9,10]}$. It has also been reported that Garcinia kola has great potential in protecting the liver cells from toxicities arising from these agents. The anti-hepatoxic efficacy of Garcinia kola has been attributed to its kolaviron content ${ }^{[6,9]}$. In these studies, the animals were mostly exposed to the toxic agents before being post treated with Garcinia kola to evaluate its hepatoprotective properties.

However, in this study, the animals were pretreated with Garcinia kola at two distinct doses considered as low dose of Garcinia kola extract $(100 \mathrm{mg} / \mathrm{kg})$ and high dose Garcinia kola extract $(800 \mathrm{mg} / \mathrm{kg})$ respectively for 7 days and on the 8 th day, they were induced with $800 \mathrm{mg}$ of acetaminophen and finally sacrificed on the 9th day. The activities of the liver enzymes ALT, AST and ALP were significantly increased $(p<0.05)$ when compared with values obtained in the control rats 
that did not receive the agent. This finding is in agreement with reports of several other researchers who reported that intoxication of the liver with acetaminophen causes liver injury and damage leading to leakage of enzymes from the hepatocytes into the plasma ${ }^{[30,31]}$. In particular, the elevation of ALT is indicative of liver damage ${ }^{[32,33]}$. These enzymes are located in the cell cytoplasm and are emptied into the circulation once the cellular membrane is damaged ${ }^{[34,35]}$. There is a growing consensus that the process resulting in the initiation of liver injury is the product of reactions that enhances the initiation of lipid peroxidation ${ }^{[36,37]}$.

Administration of Garcinia kola was observed to result in significant reduction $(p<0.05)$ in the activities of these enzymes. While no significant variation $(p>0.05)$ in means was observed between the means of the ALT and ALP between the low and high doses, a significant difference $(p<0.05)$ in mean between the doses was seen in the mean of AST. The important feature in this finding is the fact that G. kola initiated an ameliorative effect on the liver cells which resulted in the significant decrease in the levels of these enzymes in the rats administered with the various doses of $\mathrm{G}$. kola. The potential reparative and hepato-protective effect of Garcinia kola in either pretreated or post treated rats from hepatotoxins has been reported by many authors ${ }^{[38,39]}$. In this instance, it is possible that Garcinia kola extract pretreatment helps to condition the hepatocytes and its membrane, thereby protecting and reinforcing its membrane integrity against acetaminophen induced damage preventing leakage of these enzymes into the plasma.

Chemoprevention by natural products against oxidative damage and chemical hepatotoxins may be related to their intrinsic antioxidant properties. The antioxidant and scavenging activity of Garcinia biflavonoid complex has been investigated in a range of established in vitro assays. The study showed that kolaviron elicited significant reducing power and a dose-dependent inhibition of oxidation of linoleic acid by the inhibition of $\mathrm{H}_{2} \mathrm{O}_{2}{ }^{[40]}$.

MDA is a product of lipid peroxidation ${ }^{[41]}$. An increase in the MDA levels is an indication of elevated level of lipid peroxidation ${ }^{[37]}$. When extensive lipid peroxidation occurs, there is disorganization of membrane by peroxidation of unsaturated fatty acids resulting in the alteration of the ratio of poly-unsaturated to other fatty acids. This usually results in a decrease in the membrane fluidity and the death of cell ${ }^{[41]}$. In this study, following administration of acetaminophen, remarkable and significant $(\mathrm{p}<0.05)$ increase in the level of MDA in the animals in acetaminophen induced toxicity group when compared with the control animals was observed. This implies initiation of lipid peroxidation in the rats. However, in the pretreated animals, significant decrease in the levels of MDA was observed in both the low dose and high dose Garcinia kola extract groups respectively. Also in the present study, the levels of malondialdehyde in serum of acetaminophen induced toxicity group was in accordance with the recent reports of Venkatachalam et al. ${ }^{[42]}$ who reported an increase in the levels of MDA in rats treated with 1,2-dimethylhydrazine (DMH).

SOD and CAT are important in the primary cellular defense mechanism involved in the inactivation of environmental carcinogens and direct elimination of toxic free radicals and electrophiles which are responsible for oxidative injury. CAT, a haeme protein found in the peroxisomes catalyses the direct degradation of $\mathrm{H}_{2} \mathrm{O}_{2}$ into $\mathrm{H}_{2} \mathrm{O}$. Oxygen also helps to discard the hydrogen peroxides $\left(\mathrm{H}_{2} \mathrm{O}_{2}\right)$, an activity that is accelerated by the action of oxidases in these organelles. GSH-Px catalyses the reduction of peroxides $\left(\mathrm{H}_{2} \mathrm{O}_{2}\right)$ and lipid peroxides to non-toxic products and scavenges the highly reactive lipid peroxides in the aqueous phase of cell membranes using reduced glutathione as a cofactor ${ }^{[43]}$. The present study shows a decrease in the activities of SOD, CAT and GSH-Px, in the acetaminophen treated rats alone. This decrease could be due to the fact that acetaminophen produces free radicals that overwhelm the antioxidant activities of the liver enzymes. In same vein, following 7 days pretreatment with Garcinia kola which contains kolaviron, significant increases $(p<0.05)$ in the levels of these enzymes was observed. Garcinia kola could have caused the increased activities of these enzymes due to the fact that it was acting as a free radical scavenger that might destroy hepatocyte membrane integrity via oxidative damage and modulator of antioxidant enzymes. These results are 
in accordance with findings reported in other studies $^{[44-49]}$.

\section{Conclusion}

Based on these results, it can be concluded that the extracts of Garcina kola seed possesses potential prophylactic antioxidant and hepatoprotective effects in rats when given as a pretreatment before exposure to the hepatotoxic agent. These results support the traditional prophylactic use of this Garcinia kola in hepatotoxic disorders, hepatitis and jaundice.

\section{References}

1 Atawodi SE, Mende P, Pfundstein B, Preussmann R, Spiegelhalder B. Nitrosatable amines and nitrosamide formation in natural stimulants: Cola acuminata, C. nitida and Garcinia cola. Food Chem Toxicol 1995; 33(8): 625-630 [PMID: 7672735]

2 Braide, V.D. Pharmacology Effects of Chronic Ingestion of Garcinia kola Seeds in the Rats.

Phytotherapy Research, 1991, 4, 39 - 41

3 Iwu MM, Igboko OA, Okunji CO, Tempesta MS. Antidiabetic and aldose reductase activities of biflavanones of Garcinia kola. $\boldsymbol{J}$ Pharm Pharmacol 1990; 42(4): 290-292 [PMID: 1974302]

4 Tita, R. K.; Odeigah, P. G. C.; Agome, P. U.; Bassey, E. (2001). Some Properties of Medicinal Plants used by the Igbos of Nigeria. German: Wolfgang, 2001.

5 Orie, N. N.; Ekon, E. U. The bronchodilatory effect of Garcinia kola, African Journal of Pharmaceutical Science, 1993, 22, 172-201.

6 Akintonwa A, Essien AR. Protective effects of Garcinia kola seed extract against paracetamol-induced hepatotoxicity in rats. $\boldsymbol{J}$ Ethnopharmacol 1990; 29(2): 207-211 [PMID: 2374432]

7 Adaramoye OA , Adeyemi EO . Hepatoprotection of D-galactosamine-induced toxicity in mice by purified fractions from Garcinia kola seeds. Basic Clin Pharmacol Toxicol 2006; 98(2): 135-141 [PMID: 16445585 DOI: $10.1111 /$ j.17427843.2006.pto 256.x]
8 Ajibola, A.O.; Satake, M. 1992. Contributions to the photochemistry of medicinal plants growing in Nigeria as reported in the 19791990 literature-A preview. African Journal of Pharmacological Science, 1992, 22, 172-201.

9 Iwu MM. Biflavanones of Garcinia: pharmacological and biological activities. Prog Clin Biol Res 1986; 213: 485-488 [PMID: 3754968]

10 Adaramoye OA, Nwaneri VO, Anyanwu KC, Farombi EO, Emerole GO. Possible antiatherogenic effect of kolaviron (a Garcinia kola seed extract) in hypercholesterolaemic rats. Clin Exp Pharmacol Physiol 2005; 32(12): 40-46 [PMID: 15730433 DOI: 10.1111/j.1440-1681.2005.04146.x]

11 Sanchez-Valle V, Chavez-Tapia NC, Uribe M, Mendez-Sanchez N. Role of oxidative stress and molecular changes in liver fibrosis: a review. Curr Med Chem 2012; 19(28): 48504860 [PMID: 22709007]

12 Li AN, Li S, Zhang YJ, Xu XR, Chen YM, Li HB. Resources and biological activities of natural polyphenols. Nutrients 2014; 6(12): 6020-6047 [PMID: 25533011 PMCID: PMC4277013 DOI: 10.3390/nu6126020]

13 Li S , Tan HY, Wang N, Zhang ZJ, Lao L, Wong CW, Feng Y. The Role of Oxidative Stress and Antioxidants in Liver Diseases. Int J Mol Sci 2015; 16(11): 26087-26124 [PMID: 26540040 PMCID: PMC4661801 DOI: 10.3390/ijms161125942]

14 Medina J, Moreno-Otero R. Pathophysiological basis for antioxidant therapy in chronic liver disease. Drugs 2005; 65(17): 2445-2461 [PMID: 16296871]

15 Dey A, Lakshmanan J. The role of antioxidants and other agents in alleviating hyperglycemia mediated oxidative stress and injury in liver. Food Funct 2013; 4(8): 1148-1184 [PMID: 23760593 DOI: 10.1039/c3fo30317a]

16 Karabulut AB, Gul M, Karabulut E, Kiran TR, Ocak SG, Otlu O. Oxidant and antioxidant activity in rabbit livers treated with zoledronic acid. Transplant Proc 2010; 42(9): 3820-3822 [PMID: $21094863 \quad$ DOI: 10.1016/j.transproceed.2010.06.017]

17 Karber, G.Beitrag zur kollecktiven Behandlung pharmakologischer Reihenversuche. Archives 
of Experimental Pathology and Pharmacokology, 1931, 162, 480-483.

18 Lorke D. A new approach to practical acute toxicity testing. Arch Toxicol 1983; 54(4): 275-287 [PMID: 6667118]

19 Oversight of the Animal Care and Use. In: Institutional Animal Care and Use Committee Guidebook., 2nd edition, Besthesda: NIH publication, 2002, pp 35-82

20 Institute for Laboratory Animal Research (ILAR). Guide for the Care and Use of Laboratory Animal. 8th edition, Washington D.C., The National Academies Press, 2011, pp 41-104.

21 Public Health Service Policy on Humane Care and Use of Laboratory Animals. Publication of the Department of Health and Human Services. National Institute of Health.Office of Laboratory Animal Welfare, 2015, pp 1-28.

22 Folarin RO, Omirinde JO, Bejide R, Isola TO, Usende LI, Basiru A. Comparative Hepatoprotective Activity of Ethanolic Extracts of Cuscuta australis against Acetaminophen Intoxication in Wistar Rats. Int Sch Res Notices 2014; 2014: 730516 [PMID: 27433518 PMCID: PMC4897053 DOI: 10.1155/2014/730516]

23 American Vertinary Medical Association (AVMA). Guidelines for Euthanasia of Animals. American Vertinary Medical Association, 2013, Schaumburg, pp 18-42.

24 Reitman, S.; Frankel, S. A colorimetric method for determination of serum glutamate oxaloacetate and glutamic pyruvate transaminase. American.Journal of Clinical. Pathology, 1957, 28, 56-58.

25 Chuku, L.C.; Uwakwe, A.A.; Chinaka, N.C. Liver enzymes in normal and sickle cell subjects. Journal of Natural Science Research, 2012, 2(7), 1-4.

26 Ohkawa H, Ohishi N, Yagi K. Assay for lipid peroxides in animal tissues by thiobarbituric acid reaction. Anal Biochem 1979; 95(2): 351358 [PMID: 36810]

27 Aebi H. Catalase in vitro. Methods Enzymol 1984; 105: 121-126 [PMID: 6727660]

28 Misra , H. P. ; Fridovich, I . The role of superoxide anion in the antioxidation of epinephrine and a simple assay of Superoxide
Dismutase. Journal of Biological Chemistry, 1972, 247, 3170-3175.

29 Rotruck JT, Pope AL, Ganther HE, Swanson AB, Hafeman DG, Hoekstra WG. Selenium: biochemical role as a component of glutathione peroxidase. Science 1973; 179(4073): 588-590 [PMID: 4686466]

30 Obi, F. O.; Usenu, L. A.; Osayande, J.O. Prevention of carbon tertrachloride induced hepatotocixity in the rat by $H$. rosainensis anthocyanin extract administered in ethanol. Toxicology, 1998, 131, 93-98.

31 Reinke LA, Lai EK, McCay PB. Ethanol feeding stimulates trichloromethyl radical formation from carbon tetrachloride in liver. Xenobiotica 1988; 18(11): 1311-1318 [PMID: 3245227 DOI: 10.3109/00498258809042255]

32 Lin JK, Wang CJ. Protection of crocin dyes on the acute hepatic damage induced by aflatoxin B1 and dimethylnitrosamine in rats. Carcinogenesis 1986; 7(4): 595-599 [PMID: 2870820]

33 Ngaha, E. O.; Akanji, M. A.; Madusuolunmo, M. A. Studies on correlation between chloroquine-induced tissue damage and serum enzyme changes in rat. Experimentia 1989, 45,143-146.

34 LinSC, Chung TC, Ueng TH, Lin YH, Hsu SH, Chiang CL, Lin CC. The hepatoprotective effects of Solanum alatum Moench. on acetaminophen-induced hepatotoxicity in mice. Am J Chin Med 2000; 28(1): 105-114 [PMID: 10794122 DOI: $10.1142 / \mathrm{S} 0192415 X 00000131]$

35 Mohan-Rao, G. M.; Morghmom, L.O.; Kabur, M. N.; Benmohamud, B. M.; Ashibanic, K.C. Serum glutamic, oxaloacetic transaminase (GOT) and glutamic pyruvic transminase (GPT) levels in diabetes mellitus. International Journal of Medical Science, 1989, 5, 188-192.

36 Sipes IG, Krishna G, Gillette JR. Bioactivation of carbon tetrachloride, chloroform and bromotrichloromethane: role of cytochrome P450. Life Sci 1977; 20(9): 1541-1548 [PMID: 17803]

37 Tribble DL, Aw TY, Jones DP. The pathophysiological significance of lipid peroxidation in oxidative cell injury. Hepatology 1987; 7(2): 377-386 [PMID: 3549510] 
38 Iwu, M. M. Traditional Igbo Medicine. Institute of African studies, University of Nigeria, Nsukka, 1982, p 104.

39 Wegwu , M. O. ; Didia, B. 2007. Hepatoprotective effects of Garcinia kola seed against hepatotoxicity induced by carbon tetrachloride in rats. Biokemistri, 19 (1), 17 21.

40 Farombi, E.O.; Akanni, O.O.; Emerole, G.O. Antioxidative and scavenging activities of kolaviron in vitro. Pharmacology and Biology, 2002, 40, 107-116.

41 Devaki, T.; Raghavendran, H. R. B.; Sathivel, A. Hepatoprotective nature of seaweed alcoholic extract on acetaminophen-induced hepatic oxidative stress. Journal of Health Science, 2004, 50, 42-46.

42 Karthik Kumar V, Vennila S, Nalini N. Inhibitory effect of morin on DMH-induced biochemical changes and aberrant crypt foci formation in experimental colon carcinogenesis. Environ Toxicol Pharmacol 2010; 29(1): 50-57 [PMID: 21787582 DOI: 10.1016/j.etap.2009.09.006]

43 Eboh, A.S. Biochemistry of Free Radicals and Antioxidants. Scholarly Academy Journal of Biosciences, 2014, 2(2): 110-118

44 Eboh, A. S .; Ere, D.; Chuku, L. C.; Uwakwe, A. A. Kolaviron an active biflavonoid of Garcinia kola extract prevent 1,2dimethylhydrazine induced oxidative stress and lipid peroxidation in the initiation phase of colon carcinogenesis in wistar rats. Journal of Cancer and Tumor International, 2015, 2(2), 41-49
45 Oday, O. H.; Muneeb, U R.; Mir, T.; Rehan, K.; Abdul, L.; Abdul Q. K.; Wajhul, Q.; Sarwat, S. Methanolic extract of Terminali achebula protects against DMH induced colon damage in Wistar rats by restoring antioxidant enzyme activities and suppressing inflammation. International Journal of Drug Development and Research, 2014, 6 (1), 54-69

46 Adaramoye OA, Awogbindin I, Okusaga JO. Effect of kolaviron, a biflavonoid complex from Garcinia kola seeds, on ethanol-induced oxidative stress in liver of adult wistar rats. $\boldsymbol{J}$ Med Food 2009; 12(3): 584-590 [PMID: 19627207 DOI: 10.1089/jmf.2008.0138]

47 Abarikwu, S. O. Kolaviron natural flavonoids from the seeds of Garcinia kola reduces LPSinduced inflammation in macrophages by combined inhibition of IL6 secretion and inflammatory transcription factors, ERKI/2, NF-Kb, P38, Akt, p-c JUN and JNK. General Subject. Biochimica et Biophysica Acta (BBA $), 2014,1840(7), 2373$ - 2381

48 Waribo, H. A., Nwanjo, H. U.; Bartimaeus, E. S. Garcinia kola seed and vitamin E ameliorates acetaminophen-induced oxidative stress in albino rats. European Journal of Pharmaceutical and Medical Research, 2017, 4(11), 130-136.

49 Bartimaeus, E. S.; Waribo, H. A.; Nduka, N.; Nwanjo, H. U. The antioxidant effect of vitamin E pretreatment against acetaminopheninduced toxicity in albino rats. World Journal of Pharmaceutical and Life Sciences, 2018, 4(1), 05-13. 